\title{
Assessing the leeway of state-led strategic communication abroad: a comparison of news coverage on Austria, Germany, and Switzerland in Arabic
}

\author{
Andrea Häuptli ${ }^{1}$ (1) Daniel Vogler ${ }^{2}$
}

Revised: 19 August 2020 / Accepted: 1 April 2021

(C) The Author(s) 2021

\begin{abstract}
Public diplomacy programmes with the goal to enhance a country's reputation and image abroad have become wide-spread practice, also among small states with little geopolitical relevance. News media offer one of the most important platforms of their implementation. But do small states have the leeway to successfully implement their communication strategies on a global scale? Are media-based public diplomacy strategies even an option for those cases? This study assesses these questions based on international media resonance of states. Relating to the theoretical approach of country news value literature, a comparative research design is implemented. It analyses news coverage on the three German-speaking countries Germany, Austria, and Switzerland, performing a multi-level automated text analysis of 11,513 news media articles in Arabic. In accordance with existing empirical and theoretical contributions, it is shown that high-status states have more resonancebased leeway. Nevertheless, media resonance-based leeway of smaller states with lower status is caused differently, i.e. by their political, rather than their economic or military power.
\end{abstract}

Keywords Strategic communication · Public diplomacy · Global communication · Comparative research · International news flows $\cdot$ News value $\cdot$ Arab media $\cdot$ Topic model $\cdot$ Automated content analysis

\section{Introduction}

Foreign media represent a crucial element in the public diplomacy toolbox. Media function as the infrastructure of mass mediatized public spheres where public opinion is formed (Habermas 1991). Through agenda-setting, media are in an unparalleled position to influence individual opinions and ultimately public policy choices within the political process (Wu and Coeman 2009). This set up has been further accentuated in recent decades by ongoing digitalization, leading to an eased availability of information and the diversification of media offers. Consequently, public diplomacy practitioners increasingly depend on and actively

Andrea Häuptli

a.haeuptli@access.uzh.ch

1 Department of Communication and Media Research, University of Zurich, Andreasstrasse 15, 8050 Zurich, Switzerland

2 Reseach Center for the Public Sphere and Society, University of Zurich, Andreasstrasse 15, 8050 Zurich, Switzerland target foreign media in their endeavour to influence foreign publics.

Given this central role of media in combination with the global proliferation of a public diplomacy practice unrelated to immediate political outcomes but rather aiming at the maintenance of a somewhat diffuse good image abroad, public diplomacy research is in the position to investigate foreign media as a crucial factor in the evaluation and understanding of the underlying logic guiding current public diplomacy practice, and in doing so to build a much needed bridge between international relations research and communication scholarship.

Existing research establishing such links nevertheless predominantly focuses on great powers, especially the United States, as well as isolated cases of state-led communication directly related to political conflict (Banks 2011; Pahlavi 2007; Pammet 2014). It thus remains an open question in how far the very common state-led strategic communication strategies, implemented as means to enhance international country reputation independently of immediate political goals and crises, really represent a 
viable and effective public diplomacy tool for practitioners of smaller countries with limited geopolitical involvement.

This interdisciplinary paper addresses this research gap relying on country news value literature. It evaluates the strategic leeway of media resonance related public diplomacy efforts based on a state's structural attributes. Moreover, it focuses on the so far little studied smaller states. In doing so, the paper not only offers insights for public diplomacy practitioners of smaller states, but also outlines conceptual implications for further theory building from both perspectives, communication and public diplomacy research.

\section{Theoretical background, research question and hypotheses}

\section{Public diplomacy from an international relations perspective}

The departing point of our theoretical approach lies primarily in the international relations concept of "soft power", following which a state's power projection and geopolitical relevance not only depend on coercive power, but also on attraction and co-option. Consequently, a good reputation abroad and the derived legitimacy enjoyed among foreign publics, so the assumption, could figure as relevant advantage in future international conflicts and negotiations (Bjola and Kornprobst 2013; Nye 2004; Melissen 2005).

This persuasive approach to international relations, putting economic and cultural power into the limelight of geopolitics, also shapes the concept of public diplomacy beyond war-related propaganda. Public diplomacy as means to cultivate soft power, i.e. the establishment of a position from which attraction and persuasion are fostered, becomes consequently a constant task unrelated to specific conflict constellations. At the same time, such measures become available and necessary to the entire range of states seeking comparative advantages to their peers (Bátora 2005; Cooper and Momani 2011; Zerfaß and Bentele 2008).

\section{Public diplomacy practice from a functional perspective}

Given the wide-spread use of public diplomacy programmes in order to enhance country reputation or increase soft power, there is a substantial diversification of public diplomacy practice as well as of theoretical and methodological approaches analysing those efforts. The different functional perspectives can be summarized based on the following categorization (Fitzpatrick 2010):
(1) Advocacy/Influence: one-way influence on attitudes, opinions, and behaviours of foreign publics; mainly through media exposure

(2) Communication/Information: one-way distribution of information in order to inform and educate foreign citizens about a nation and its policies

(3) Relation: two-way establishment of beneficial relationships with people in other countries

(4) Promotion: promotion of particular aspects of a nation to foreign publics

(5) Political mobilization: engage in national or international politics

(6) Warefare/propaganda: support/complement military efforts

\section{The strategic relevance of news media for small states}

We argue that especially for small states with limited resources, the first perspective, i.e. one-way advocacy through media exposure, plays a central role in the implementation of their communication strategies abroad, as the other means are more cost-intensive and harder to implement on a global scale. As information about foreign nations and their policy goals is generally scarce, mass media figure as main information supplier to foreign publics and thus substantially impact a state's reputation abroad. Studies found that exposure to news coverage increases knowledge about a foreign nation and influences its perception by foreign publics (Albritton and Manheim 1983; Albritton and Manheim 1985; Brewer et al. 2003; Perry 1985). Research further suggests that strategic communication efforts of states can succeed in influencing agenda-setting by the media, and in doing so, public perception (Lee and Hong 2012; Manheim and Albritton 1984). For states it is thus of strategic relevance to make specific information available abroad through mass media in order to impact the formation of individual perceptions and ultimately public opinion (Brewer et al. 2003).

Although practitioners and experts have recurrently advocated for a diversification of strategic communication efforts including other functional perspectives (Cowan and Arsenault 2008), such efforts can only be complementary to the strategic centrality of news media abroad. Other forms of strategic communication establishing direct channels to reach local populations, e.g. cultural events and educational programmes aiming at dialogue and collaboration (Cowan and Arsenault 2008), have potentially very positive effects, yet, besides their cost-intensiveness, their potential scope will always remain limited compared to the resonance generated by mass media.

Targeting individual (and ultimately public) perception abroad through media moreover offers the strategic 
advantage that states can shape public relations directly by issuing relevant statements aiming to be picked up by the media. As characterized by Cowan and Arsenault (2008, p. 13), this "monologue-based" type of information emanates directly from within the political system and it is expressed by administrations and executives, giving the state maximum leeway over its content. Monologue-based communication in this context serves thus the main purpose to orient the broad public through news media about a state's policy standpoint and values on a day-to-day basis. This in contrary to the "dialogue-based" types of communication (such as relation or promotion), where the more diverse and often non-political representatives of the emanating state cannot always be coerced to follow the state's strategy. It is thus within the political foreign news coverage abroad that states can most directly pursue goals set by communication strategies.

Ultimately and most importantly for this research, this type of communication is restricted by the amount of attention political news coverage on a given state gets, making resonance a key factor for media-related communication strategies. Relating this aspect to the outlined research gap concerning the evaluation of strategic communication efforts of smaller states, the following research question is assessed: What factors pre-determine the resonance in news media abroad and how does this affect the leeway of small states' strategic communication?

\section{Media resonance-based strategic leeway: determining factors}

As communication scholarship outlines, two main limitations result from the relevance of politics-related media resonance as central factor for state-led strategic communication abroad.

The first limitation derives from the fact that states depend on getting scarce media attention abroad. Studies found that not every state can achieve the same amount of political news coverage abroad (Gerbner and Marvanyi 1977; Golan 2008; Wu 2000). Schulz (1976) and Staab (1990) distinguish between two determining factors leading to different amounts of attention directed to a given state: status and proximity. Status stands for a country's potential to influence geopolitics and has been conceptualized based on the following dimensions: size (Kim and Barnett 1996; Wu 2000; Wu 2016) as well as political, military and economic power (Galtung and Ruge 1965; Golan and Wanta 2003; Hagen et al. 1998; Östgaard 1965; Westerståhl and Johansson 1994). Proximity in turn is a relational concept, bearing the dimensions geographic distance (Hagen et al. 1998; Westerståhl and Johansson 1994), intensity of bilateral economic and military cooperation (Golan and Wanta 2003; Hagen et al. 1998; Westerståhl and Johansson 1994), as well as cultural similarities between two given countries (Hagen et al. 1998; Kim and Barnett 1996). Yet, only bilateral economic cooperation has been consistently identified as significant predictor for news coverage abroad (Ahern 1984; Dupree 1971; Hagen et al. 1998; Wu 2003).

Concerning the volatility of news coverage on states abroad, Kamps (1998) found that countries with high status get regularly covered, whereas low-status countries get more selective, event-dependent news coverage. Moreover, high-status states not only get more news coverage, they also appear in a wider range of topic areas (e.g. politics, economy, sports), whereas states with lower status get coverage limited to specific areas, such as war and conflict. Other studies are in line with those findings, considering events as central drivers for the coverage of states abroad, attributing their news value to the established factors such as surprise, success, conflict and damage (Schulz 1976; Staab 1990; Tiele 2010). Nevertheless, and crucially, they still consider the status of a country as primary predictive factor for their news-worthiness (Chang 1998; Galtung and Ruge 1965; Golan 2010; Golan et al. 2010; Hagen et al. 1998).

The outlined findings implicate that countries with high status have the broadest and most steady leeway in their communication strategies, as they can be assured to get stable media coverage less affected by selective events. States with lower status, in turn, will play a lesser role in foreign news coverage abroad in general, exposing them to more event-based volatility. Taken together, these findings also implicate that states with lower status are more limited when it comes to the geographic spread of their news coverage. As high-status countries have the economic leverage to maintain significant economic ties with a wider range of countries, their news coverage abroad will spread further than the one on states with lower status, maintaining only selectively significant economic ties. Based on this first limitation, the following hypotheses result:

H1 States with comparatively low status get less resonance abroad through political news coverage than states with higher status.

H2 States with comparatively low status get less steady resonance through political news coverage abroad than states with more status.

H3 There is less thematic diversity in news coverage on states with comparatively low status than on states with higher status.

H4 There is less geographic diversity in news coverage on states with comparatively little economic power than on states with more economic power. 
The second limitation of state-led strategic communication derives from the fact that the hegemony of the state in shaping its perception in public spheres abroad is limited to the political realm. States do not own their name exclusively, as private individuals and firms are linked to their countries of origin and can be portrayed as representatives of their nation. Although state officials may wish to increase media coverage topic-independently, they only figure as direct stakeholders within political news coverage, where they can directly try to implement public relation efforts. Consequently, outside of official political communication (such as official press releases, speeches, etc.), media attention towards private nationals can interfere with strategic goals set by the state. Based on the findings of Kamps (1998), the thematic diversity of news coverage is higher for high-status states, leaving them with the biggest potential of interference from outside the political realm. Based on the second limitation, the following hypothesis is derived:

H5 States with comparatively low status get more resonance through political than non-political news coverage.

\section{Methods}

\section{Case selection and data collection}

News coverage on the three German-speaking countries Germany, Switzerland, and Austria was selected to test the hypotheses. This selection offers the necessary variance on the independent variable "status". Germany performs in all of the outlined dimensions best, whereas Switzerland outperforms Austria in the dimensions military and economic power. Given this specifically European test sample, political power was operationalized in addition to the indicators identified by the discussed literature as European Union membership, leading to Austria outperforming Switzerland in this dimension (c.f. Table 1).

The analysis focuses on online news coverage on the three countries in Arabic. The Arab region is culturally and geographically distant from the analysed countries. This leads to an increased relevance of media coverage as other forms of strategic communication get more cost-intensive and challenging. The Arab media arena represents thus a relevant case. It is moreover of high social relevance for the three analysed countries in the context of recurrent Islamist terror

Table 1 Status dimensions overview

\begin{tabular}{|c|c|c|c|c|}
\hline Dimensions & Operationalization & Germany & Switzerland & Austria \\
\hline \multirow[t]{2}{*}{ Size } & $\begin{array}{l}\text { Population size }^{\mathrm{a}} \\
\text { (Dupree 1971; Jones et al. } \\
\text { 2012; Kim and Barnett } \\
\text { 1996; Westerståhl and } \\
\text { Johansson 1994; Wu 2000, } \\
\text { 2003) }\end{array}$ & $\begin{array}{l}82.29 \text { million (2018) global } \\
\text { rank } 17\end{array}$ & $\begin{array}{l}8.54 \text { million (2018) global } \\
\text { rank } 99\end{array}$ & $\begin{array}{l}8.75 \text { million (2018) global } \\
\text { rank } 98\end{array}$ \\
\hline & $\begin{array}{l}\text { Geographic surface } \\
(\mathrm{Wu} 2000 ; \mathrm{Wu} 2016)\end{array}$ & $348.560 \mathrm{~km}^{2}$ global rank 63 & $39.516 \mathrm{~km}^{2}$ global rank 132 & $82.409 \mathrm{~km}^{2}$ global rank 113 \\
\hline \multirow[t]{2}{*}{ Political power } & $\begin{array}{l}\text { Permanent UN-security coun- } \\
\text { cil seat (Schulz 1982) }\end{array}$ & No & No & No \\
\hline & EU-membership & Yes & No & Yes \\
\hline \multirow[t]{2}{*}{ Military power } & $\begin{array}{l}\text { Military expenditure (Golan } \\
\text { and Wanta 2003; Hagen } \\
\text { et al. 1998; Schulz 1976; } \\
\text { Staab 1990; Westerståhl and } \\
\text { Johansson 1994) }\end{array}$ & 44329 m. US\$ (2018) & $4630 \mathrm{~m} . \mathrm{US} \$(2018)$ & 2970 m. US\$ (2018) \\
\hline & Nuclear power & No & No & No \\
\hline Economic power & $\begin{array}{l}\text { GDP }^{\mathrm{d}} \\
\text { (Ahern 1984; Dupree 1971; } \\
\text { Hagen et al. 1998; Jones } \\
\text { et al. 2012; Kim and Barnett } \\
\text { 1996; Staab 1990; Wester- } \\
\text { ståhl and Johansson 1994) }\end{array}$ & $\begin{array}{l}\text { 4,000,386 m. US\$ global } \\
\text { rank } 4\end{array}$ & $\begin{array}{l}703,750 \mathrm{~m} . \text { US } \$ \text { global rank } \\
20\end{array}$ & $\begin{array}{l}457,637 \mathrm{~m} . \text { US } \$ \text { global } \\
\text { rank } 26\end{array}$ \\
\hline
\end{tabular}

${ }^{\mathrm{a}}$ Worldometers

${ }^{\mathrm{b}}$ Worldometers

${ }^{\mathrm{c}}$ Stockholm International Peace Research Institute, 2018

${ }^{\mathrm{d}}$ International Monetary Fund, 2018 
attacks (Zaharna 2010) and substantial migration flows to Europe since the political turmoil in the region triggered by the Arab spring in 2011 and the subsequent Syrian Civil War (Organisation for Economic Cooperation and Development 2019; Statistisches Bundesamt 2020). The analysis represents moreover a scientific novum, as there is a general bias in this research field towards the Western world and the analysis of media arenas of perceived importance to great powers (Melissen 2005).

The target public was conceptualized based on a linguistic rather than national criterion, leading to an analysis of online news offers in Arabic mentioning the three countries between the 1st of August and the 31st of December 2018, independently of the respective country of origin of the offer. This approach takes into consideration the potential of online media to be used place-independently in general, and especially in the case of Arabic-speaking audiences. Modern Standard Arabic is widely understood, not only by citizens of the 22 states of the Arab League but also by minorities and diaspora communities all over the world. Media content offered in Arabic is thus accessible to a very broad audience, independently of national borders. Accordingly, studies show that media consumption throughout the Arab region is indeed transnational in nature, challenging the conceptualization of the exclusive relevance of national media outlets to the formation of public opinion in the Arab states (Ayish 2012; Haeuptli 2019; Sarnelli and Lomazzi 2019). According to these research findings, the analysis focuses on media in Arabic as belonging to one arena, rather than on a specific Arab country.

Following this linguistic criterion, the data was collected inductively using Google Alerts for the respective state names and demonyms in Arabic. Google Alerts is recurrently used in various research fields as a tool to monitor news coverage (Siegner et al. 2018; Voumard et al. 2018; Weichelt et al. 2018). This inductive approach offered the main advantage to potentially include any media outlet relevant in this topic field. The online media landscape in the Arab region is generally underexamined, leading to a lack of information on the importance of traditional and legacy media outlets and on the abundance of new online media players in a politically changing environment as well. An uninformed preselection of media outlets was thus avoided and, especially, the reinforcement of the recurrent focus on Arab legacy media. The vast array of new and old professional online media in Arabic offering news coverage on the three states was thus included.

The hits were reviewed manually to exclude non-news content, as well as to identify professional news sources and their country of origin. Consequently, the term "online news" used in this paper encompasses all text-based news content from sources offering professional journalistic content online. This focalization on professional news also reflects the uncontested relevance of established professional media for public opinion formation in the Arab region. Even if the relevance of Social Media and Citizen Journalism is recurrently underlined, professional journalism was found to remain a central and the most far-reaching source of information for Arab publics (Aday et al. 2013). The definition applied to distinguish professional journalism was as follows: the presence of a consistent identifying name of the news offers, a permanent editorial (core) team, and some regularity of publication or upload of new contents. The manual review of the news sources led to a data base of 11,513 entries from 1175 different sources. The quality of content-identification was moreover cross-checked via research functions on randomly selected news sites and led to satisfactory results.

Given the inductive approach, the resulting sample of news outlets in the dataset is indeed characterized by diversity, including small local news offers or special interest outlets as well as prominent international news outlets such as Aljazeera or CNN Arabic. To account for the varying importance of those outlets within the Arab media arena, a weighting of each article based on the total visits of the respective news site in the relevant period was introduced. The relevance of each article within the analysis was thus based on the reach of its corresponding news site. In cases where the total visits indication was missing, the value was estimated based on the global rank of the site (c.f. Similarweb).

\section{Data analysis}

To structure the media articles, topic modelling based on latent Dirichlet allocation LDA was performed (Blei et al. 2003). Topic modelling is a method for automated content analysis "designed to automatically organize large archives of documents based on latent topics, measured as patterns of word (co-)occurrence" (Jacobi et al. 2015, p. 89) The analysis was conducted in the R Studio environment by using the topicmodels (Grün and Hornik 2011) and the tm package (Feinerer et al. 2008). Media articles were split into three distinct text corpuses, each including the media articles for a single country. As Arabic cannot be processed with the common text processing programmes in $\mathrm{R}$, media articles were translated with Google Translate from Arabic into English. The analysis was limited to titles and the first 150 characters of each article, as the topic of an article was considered to be expressed most prominently within title, lead and/or the first lines. Although topic model has been applied to text corpora in Arabic (e.g. Kelaiaia and Merouani 2013; Marwa et al. 2017) Google Translate is shown to deliver valid results and is thus considered as "a useful tool for comparative researchers when using bag-of-words text models" (Vries et al. 2018, p. 417). 
One topic model for each of the three text corpora was run. Before modelling, the texts were prepared by transforming all characters to lower case and excluding special characters and common English stop words, excluding a customized list of stop words. Perplexity tests for the three corpora were run identifying 40 topics (Austria, Switzerland), and 35 topics (Germany) as best fits. As one of the authors of this paper is fluent in Arabic, the quality of the automated translation and the plausibility of the results by comparing the topics with the original articles were assured. Random checks delivered a satisfactory picture of the topic assignment. In a final step, the 115 topics from the three models were manually assigned to six overarching thematic areas (politics, economy, culture, religion, sports, human interest). As a quality check, random sample of 34 topics stemming from all three countries (about $30 \%$ of total topics) was moreover independently assigned by a second coder, leading to identical assignments of overreaching thematical areas in $91 \%$ of the cases (31 of 34 cases).

To measure the geographical and thematic diversity of the media coverage of each state Shannon Index $(\mathrm{H})$ was used, a diversity measure used for populations (Spellerberg and Fedor 2003). To calculate Shannon $H$ of a given population the total amount of $\mathrm{N}$ individuals of $\mathrm{S}$ different species each with $\mathrm{n}$ individuals is used. For this case this means that $\mathrm{N}$ represents the number of media articles $(N=11.513)$ which belong to different topics $(S=6)$ or appear in the identified target countries $(S=52)$, respectively. The value of $\mathrm{p}$ is therefore the share of media articles of a topic or target country of the total amount of coverage $N$. Shannon $H$ is the sum of the values of $p$ for all topics (or target countries) multiplied with the natural logarithm of $p$ :

$H=\sum_{i} p_{i} \times \ln p_{i}$ with $p_{i}=\frac{n_{i}}{N}$

\section{Results and discussion}

\section{Hypotheses}

In hypothesis one it was assumed that states with comparatively low status get less resonance abroad through political news coverage than states with higher status. The analysis showed that this assumption does not hold consistently, as only Switzerland got less resonance within the political realm (1322 politics-related weighted hits) than the other states, with low-status Austria even getting slightly more politics-related resonance (1999) than Germany (1917; c.f. Table 2). Hypothesis one has thus to be rejected.

Addressing resonance volatility over time, hypothesis two assumed that states with comparatively low status get less steady resonance through political news coverage abroad than states with high status. This hypothesis is confirmed by the lower standard deviation (SD = 109.23) for Germany compared to Austria (SD = 161.42), and Switzerland (SD = 195.78; c.f. Table 2). Hypothesis two can thus be preliminarily accepted. The finding is further confirmed by the resonance range (visualized in Fig. 1). Germany has the narrowest range. The difference between the month with lowest and the highest politics-related resonance makes up for $14.6 \%$ of the total politics-based resonance. Austria got a slightly wider range, the difference represents $17.3 \%$ of total politics-based resonance. The results for Switzerland in turn showed a high range, with a maximum difference of $35.2 \%$ of total politics-based news coverage.

Hypothesis three assumed thematic diversity to be higher for high-status states than for low-status states. The Shannon Index showed that Germany gets thematically the most diverse resonance (Shannon $H=1.45$ ). The data shows that the resonance of Switzerland is diverse to a comparable extent $(H=1.34)$, with Austria displaying the least thematically diverse resonance $(H=0.92)$. Hypothesis three can only be accepted partially, as Germany with clearly the highest status gets the most thematically diverse resonance, yet with status not accounting for the difference in thematic diversity between Austria and Switzerland.

Concerning geographic diversity, it was assumed in hypothesis four that states with more economic power perform better than states with lower economic power. This hypothesis is accepted based on the highest diversity for Germany $(H=2.81)$, followed by Switzerland, $(H=2.53)$ and Austria $(H=2.45)$. This ranking in diversity follows the ranking of economic power, with Germany in the first place and Switzerland ranking clearly higher than Austria.

Table 2 Results for each country

\begin{tabular}{lllllllll}
\hline Country & Total hits & $\begin{array}{l}\text { Total } \\
\text { politics- } \\
\text { related hits }\end{array}$ & $\begin{array}{l}\text { Total hits } \\
\text { weighted }\end{array}$ & $\begin{array}{l}\text { Total politics- } \\
\text { related hits } \\
\text { weighted }\end{array}$ & $\begin{array}{l}\text { Shannon Index } \\
\text { thematic diver- } \\
\text { sity }\end{array}$ & $\begin{array}{l}\text { Shannon Index } \\
\text { geographic } \\
\text { diversity }\end{array}$ & $\begin{array}{l}\text { Shannon Index } \\
\text { geographic diversity } \\
\text { politics-related }\end{array}$ & $\begin{array}{l}\text { Resonance } \\
\text { volatility } \\
\text { SD }\end{array}$ \\
\hline Germany & 3973 & 2029 & 3862 & 1917 & 1.45 & 2.81 & 2.84 & 109.23 \\
Austria & 3813 & 2374 & 3129 & 1999 & 0.92 & 2.45 & 2.44 & 161.42 \\
Switzerland & 3727 & 1296 & 4459 & 1322 & 1.34 & 2.53 & 2.51 & 195.78 \\
\hline
\end{tabular}




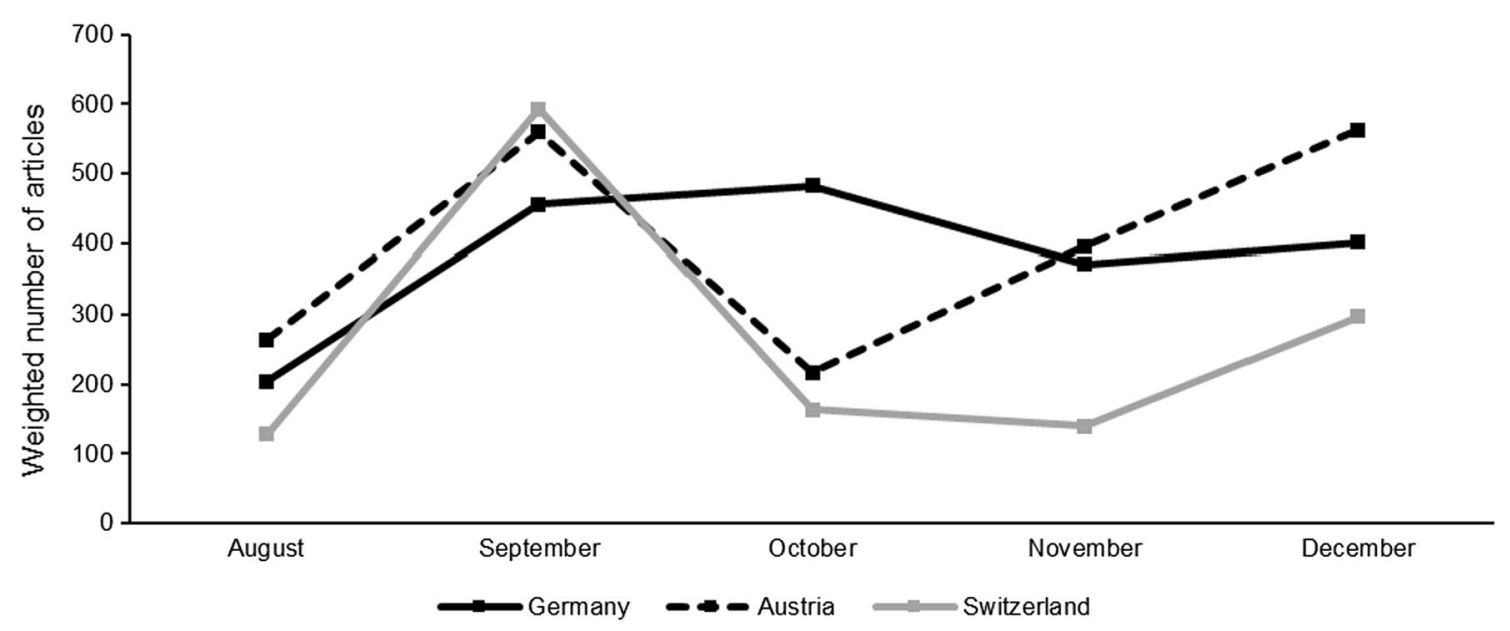

Fig. 1 Politics-related resonance over time

In hypothesis five, it was assumed that states with comparatively low status get more resonance through political than non-political news coverage. The comparison of politics-based and non-political resonance shows that this assumption does not hold. Germany got almost equal resonance in the two categories (1917 politics-based to 1945 non-politics), Austria got by far more politics-based resonance (1999 to 1129), and Switzerland got by far more nonpolitical resonance (1322 to 3137 weighted articles; c.f. Fig. 2). Hypothesis five is thus rejected.

\section{The nature of politics-related news coverage}

In order to give more analytical depth to the outlined findings, an in-depth analysis of the politics-related topics for each country was performed. Table 3 shows the top-ten politics-related topics for each country ranked following the weighted resonance they achieved. Their share of the total politics-related weighted resonance is indicated as percentage. The entire list of topics with their respective weighted resonance can be found in the Appendix (Table 4).

The comparison shows that the found volatility of news coverage of smaller states is not driven by few single events. Although the first ranked topic in the case of Austria and Switzerland got substantially more news coverage, the remaining topics show very similar shares and represent in both cases about $85 \%$ of total politics-related news coverage. The topics also show that, against the discussed findings of the literature (Kamps 1998; Tiele 2010), lower status states do not predominantly attract media attention through war and conflict. Compared to Germany, Austria and Switzerland show similar amounts of conflict-burdened topics (such as migration or international disputes) with similar amounts of attention driven towards them as compared to

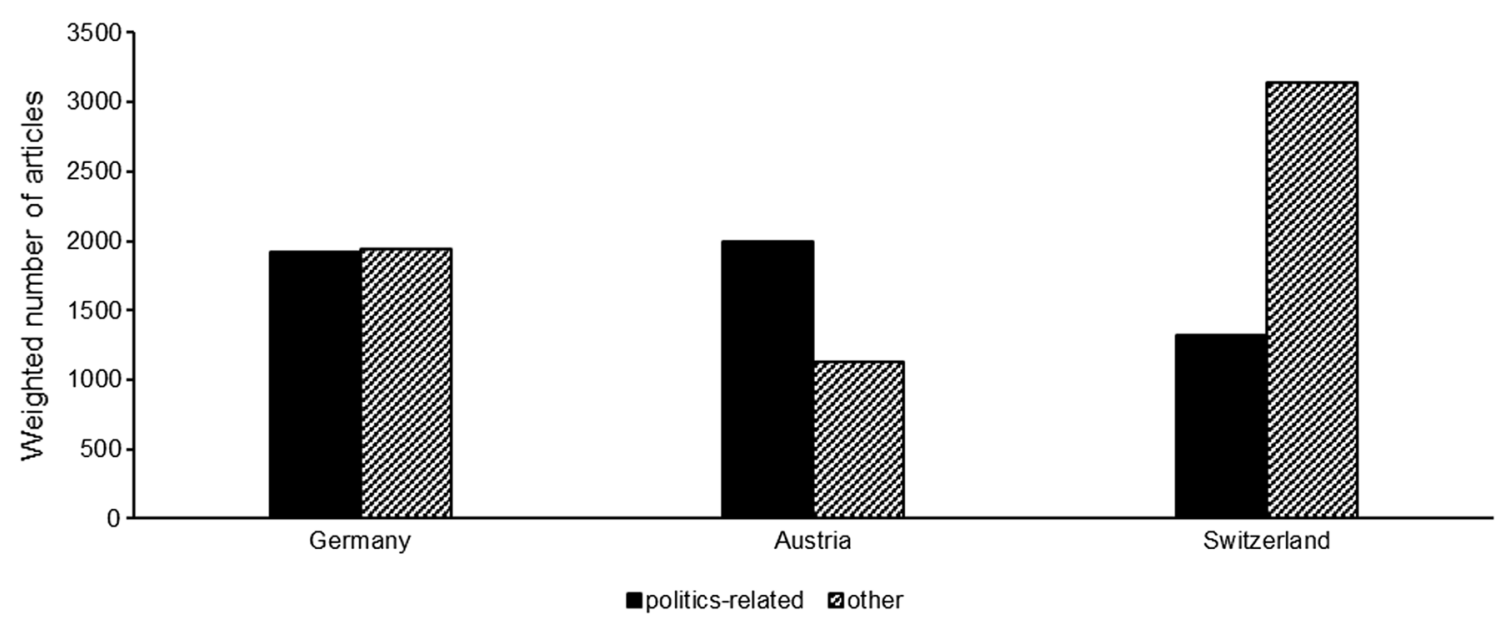

Fig. 2 Politics-related vs. other resonance 
Table 3 Top ten politics-related topics for each country, relevance in \% of total politics-related weighted resonance

\begin{tabular}{|c|c|c|c|c|c|c|}
\hline Rank & Germany & $\%$ & Austria & $\%$ & Switzerland & $\%$ \\
\hline 1 & European migration policies & 11 & State visit As-Sisi & 14 & Vote on unconditional basic income & 15 \\
\hline 2 & Government dispute & 8 & $\begin{array}{l}\text { Putin assists wedding of Austrian foreign } \\
\text { minister }\end{array}$ & 10 & $\begin{array}{l}\text { Yemen/Western Sahara negotiation in } \\
\text { Geneva }\end{array}$ & 8 \\
\hline 3 & German aid to Tunisia & 8 & Commemoration WWI & 9 & Tax evasion/dictator money & 8 \\
\hline 4 & Killing of Khashoggi & 7 & Ambassador visit in Egypt & 9 & Bilateral relations to various Arab states & 7 \\
\hline 5 & Sanctions to Iran & 7 & $\begin{array}{l}\text { Austrian foreign minister speech in Arabic } \\
\text { at UN }\end{array}$ & 6 & Swiss state visit in Lebanon & 7 \\
\hline 6 & Bilateral meeting Kuwait & 6 & Muslim Brotherhood in Austria & 5 & Russian spying & 7 \\
\hline 7 & Syrian refugees & 5 & Migration & 5 & $\begin{array}{l}\text { Swiss-Egyptian dispute Pharaoh Khufu } \\
\text { statue }\end{array}$ & 7 \\
\hline 8 & German-Turkish relations & 5 & EU summit in Salzburg & 5 & $\begin{array}{l}\text { Killing of Khashoggi/bilateral relations to } \\
\text { Saudi Arabia }\end{array}$ & 7 \\
\hline 9 & Right-wing protests/migration & 5 & Racism/migration & 4 & Arm exports to UAE & 6 \\
\hline 10 & Work migration law & 5 & Various bilateral meetings & 4 & Vote on prohibition of burkas/veils & 5 \\
\hline
\end{tabular}

other politics-related topics. Daily foreign politics, i.e. the staging of international relations through visits and talks, represent a substantial part of news coverage, also on smaller states. Especially Austria managed to appear in those topic areas as active stakeholder, pointing at the strategic leeway of smaller states with political power to influence media coverage directly.

The comparison shows also that the majority of politics-related topics relate to the Arab region. The topics are geographically related (politics affecting a country of the Arab region or neighbouring) but also thematically related through the link of migration, the treatment of minorities and religion. Exclusively domestic politics with no connection to the Arab region were in turn reported when they were of general geopolitical interest (mostly in the case of Germany), reflecting the thematically more diverse news coverage of high-status states. In the cases of the geopolitically less relevant states, domestic politics or relations to non-Arab states are mostly reported when they carry an element of surprise (such as in the case of basic income in Switzerland) or scandal (such as the attendance of the Russian president at the wedding of the Austrian Foreign Minister) pointing at the relevance of those news value elements in shaping political news coverage of smaller states abroad.

\section{Limitations}

This study used an innovative and highly inductive approach with its own limitations. First, the analysis was over a rather short period. This may lead to events, rather than structural factors of political, economic or military power, defining the resonance of the analysed states. Although this could be excluded for the politics-related news coverage, there is at least a possibility of the coincidence of multiple single events drawing media attention. Studies including more countries over a longer period are thus necessary in order to consolidate the findings. Second, the method used is based on data collection and machine translation with Google applications. Although both tools are shown to deliver valid results (e.g. Vries et al. 2018) and are widely used by researchers, more transparency on the procedures implemented by these tools would be desirable for further assessment. Third, media offers were selected based on a linguistic criterion, shifting away from the recurrent focus on few and well-known news outlets (Samei 2015; Seib 2014). This accounts for the fact that media production and consumption within a given country is not restricted to its borders, with digitalization rendering them increasingly porous (Castells 2010). The potential for a de-nationalized communicative arena is moreover especially high in the Arab world, as the absence of language-barriers facilitated transnational media production and consumption early on, including media offers from outside the Arab world (Abdulla 2007; Ayish 2012; Ayish et al. 2013). This approach nevertheless only accounted for geographic diversity based on the country of origin of news offers, rather than the actual location of their consumption. Further studies should include this aspect, taking into consideration media consumption patterns of Arabic-speaking users. At the same time, more research on the spread of news within the increasingly integrated Arab media arena could inform strategic communication researchers and 
practitioners on what type of media outlets play an in important role in reaching the broadest Arab audience.

\section{Conclusions}

This study is based on the main assumption that politicsrelated resonance in news media of a target region widens the leeway for strategic communication of a state in said region. The analysis of news articles in Arabic on Germany, Austria, and Switzerland shows that high-status states, i.e. Germany, receive more resonance than low-status states and thus possess larger leeway for strategic communication. In line with existing literature (Wu 2000), the study at hand shows that Germany got a comparatively high amount of politics-based resonance, which was also shown to be the steadiest over time. Moreover, Germany's resonance proved to be geographically most diverse, pointing at leeway on a global scale. Nevertheless, and as predicted, the analysis showed a status-independent reduction of leeway due to a high share of non-political resonance, at almost equal levels with political resonance, and high thematic diversity. This points at the possibility of non-political actors to interfere with the goals of state-led communication strategies, as the media attention driven towards companies, NGOs, athletes and tourists will necessarily reflect their own strategic communication goals, if present, rather than those of their country of origin. On a practical level, these findings point at the possibility for German state officials to use media relations as a viable tool in order to impact public opinion abroad, on a steady basis.

Yet, what is the resonance-based leeway of small states' strategic communication abroad? The results show that not every dimension of status has the same predictive strength. Compared to Switzerland, Austria gets more and steadier politics-based resonance, with less thematic diversity. Politics-based resonance makes also up for a higher share of its total resonance as compared to Switzerland. According to the main pre-assumption of this paper, such resonance defines strategic leeway, since it is within the political realm where Austrian officials can take an active role as direct stakeholders. On an aggregated level, status cannot explain these differences, as Austria and Switzerland have similar status. Nevertheless, they perform differently within the status dimensions, Austria possessing more political power, and Switzerland more military and economic power. Given this variance, political power seems to be the crucial factor for smaller states driving the strategically relevant politicsbased resonance abroad. This preliminary result is plausible, as Austria is an active stakeholder within the European Union when it comes to migration flows triggered by the
Syrian Civil War, a topic area of specific interest for the Arabic-speaking media and public. International attention towards the European Union could thus trigger attention by proxy to the member states. Yet, the more detailed analysis of topics showed that Austria attracts politics-related media attention also unrelatedly of the European Union. This finding points at the relevance of political power for the potential to shape a good reputation abroad and, by extension, enhancing the soft power of small states. For small states, political activity in international organizations thus not only affects relation with present stakeholders but can impact also their perceptions in apparently uninvolved geographic regions. This finding may lead to a reconsideration of the importance of "classical" political activity on the international stage from the perspective of soft power enhancement. Further studies analysing more countries over a longer period will nevertheless have to show whether political power is consistently more relevant than other dimensions of status when it comes to the politics-based resonance of small states, also outside the specific context of the European Union. On a theoretical level, the findings point at the potential necessity to operationalize political power, in analogy to proximity, as a relational concept based on the case pairs analysed: Depending on them, political power or relevance in given policy areas would figure as more or less important, leading to varying news coverage on a given state.

Relating the results to strategic leeway, smaller states do have the potential to impact news coverage abroad directly and from within the political system, as the case of Austria shows. Nevertheless, in cases of states with limited political power, the impact of according strategies remains also limited. Communication strategies oriented towards media are in these cases comparatively ineffective as the bulk of media coverage is oriented towards topic areas outside the realm of state influence. Consequently, public diplomacy practitioners and decision-makers of small states will have to consider their communication strategies in light of the attributes of their countries. In the case of Switzerland for instance, a high investment in media-based state-led strategic communication has shown to be ineffective and the country could be better off in investing in different types of public diplomacy efforts in order to achieve an enhancement of their reputation abroad and ultimately soft power.

Funding Open Access funding provided by Universität Zürich.

\section{Declarations}

Conflict of interest The authors declare that they have no conflict of interest.

Appendix See Table 4. 
Table 4 Topics per country and total weighted resonance per topic

\begin{tabular}{|c|c|c|c|c|c|c|}
\hline \multirow{2}{*}{$\frac{\text { Rank }}{1}$} & \multicolumn{2}{|l|}{ Germany } & \multicolumn{2}{|l|}{ Austria } & \multicolumn{2}{|l|}{ Switzerland } \\
\hline & Football & 385 & $\begin{array}{l}\text { Putin assists wedding of Austrian foreign } \\
\text { minister }\end{array}$ & 192 & Swiss football trainer (Zamalek EGY) & 314 \\
\hline 2 & Football & 231 & Football & 183 & Football & 296 \\
\hline 3 & European migration policies & 212 & Commemoration WWI & 181 & Football & 204 \\
\hline 4 & Football & 197 & Ambassador visit in Egypt & 175 & Vote on unconditional basic income & 201 \\
\hline 5 & Human interest & 186 & $\begin{array}{l}\text { Austrian foreign minister speech in Arabic } \\
\text { at UN }\end{array}$ & 117 & Football & 195 \\
\hline 6 & Government dispute & 155 & Film festival in Marrakesh & 114 & Tennis (Roger Federer) & 187 \\
\hline 7 & Aid to Tunisia & 153 & Football & 110 & Pirates hijack Swiss citizens & 151 \\
\hline 8 & Killing of Khashoggi & 142 & Muslim Brotherhood in Austria & 109 & Swiss businesses & 146 \\
\hline 9 & Football: Bayern Munich & 135 & Football & 105 & $\mathrm{HI} /$ crime & 129 \\
\hline 10 & Sanctions Iran & 130 & Terrorist incidents & 102 & Football & 124 \\
\hline 11 & Human interest & 114 & Migration & 102 & Small plane crash & 122 \\
\hline 12 & Bilateral meeting in Kuwait & 109 & EU summit in Salzburg & 91 & Football & 122 \\
\hline 13 & Education centre in Cairo & 107 & Racism/migration & 85 & FIFA scandal & 122 \\
\hline 14 & Syrian refugees & 103 & Various bilateral meetings & 82 & Exhibition in Luxor & 121 \\
\hline 15 & German-Turkish relations & 98 & State visit As-Sisi & 78 & $\begin{array}{l}\text { Yemen/Western Sahara negotiation } \\
\text { Geneva }\end{array}$ & 111 \\
\hline 16 & Right-wing protests/migration & 96 & Phone call AU-EGY ${ }^{\mathrm{a}}$ & 78 & Theatre/film & 110 \\
\hline 17 & Work migration law & 91 & Austrian court rulings (various crimes) & 73 & Swiss economy developments & 102 \\
\hline 18 & Erdogan visit & 90 & Visit As-Sisi in Vienna ${ }^{a}$ & 72 & Tax evasion/dictator money & 101 \\
\hline 19 & Migration & 87 & Russian spying & 69 & Swiss currency & 100 \\
\hline 20 & Military intervention Syria/Iraq & 86 & Sports: Mohammed Salah & 68 & Bilateral relations various Arab states & 98 \\
\hline 21 & Airport security & 84 & Art & 64 & Swiss state visit in Lebanon & 97 \\
\hline 22 & Plane crash & 83 & Crime & 64 & Russian spies & 97 \\
\hline 23 & Suspected terrorist arrested & 82 & War in Syria & 61 & $\begin{array}{l}\text { Swiss-Egyptian dispute Pharaoh Khufu } \\
\text { statue }\end{array}$ & 95 \\
\hline 24 & Trade relations to Egypt & 79 & Education & 60 & Art and landscape & 92 \\
\hline 25 & German economy & 76 & European migration policies & 58 & $\begin{array}{l}\text { Killing of Khashoggi/bilateral relations to } \\
\text { Saudi Arabia }\end{array}$ & 92 \\
\hline 26 & Sexual harassment & 73 & Prohibition of veils & 57 & Football & 85 \\
\hline 27 & Funding of religious groups & 73 & Expo Dubai & 56 & Medical research & 79 \\
\hline 28 & Human interest & 64 & Various sports & 55 & Arm exports to UAE & 75 \\
\hline 29 & Islam & 56 & $\begin{array}{l}\text { International agreements on trade/energy/ } \\
\text { tourism }\end{array}$ & 54 & Domestic politics: vote on veils & 73 \\
\hline 30 & Work strikes & 55 & Visit As-Sisi in Vienna $^{a}$ & 52 & Gift scandal & 70 \\
\hline 31 & Russia-Germany relations & 54 & Yemen peace negotiation & 49 & Football & 67 \\
\hline 32 & German businesses & 51 & Killing of Khashoggi & 45 & $\begin{array}{l}\text { Treatment of Algerian president Boutef- } \\
\text { lika in Geneva }\end{array}$ & 66 \\
\hline 33 & Tourism & 50 & Economic cooperation AU-EGY ${ }^{\mathrm{a}}$ & 43 & Olympics & 66 \\
\hline 34 & Commemoration end of WWI & 38 & $\begin{array}{l}\text { King Abdullah bin Abdulaziz Interna- } \\
\text { tional Centre for Dialogue in Vienna }\end{array}$ & 41 & Rejected citizenship to migrants & 63 \\
\hline 35 & $\begin{array}{l}\text { Statement by politicians: agri- } \\
\text { culture, economy, migration }\end{array}$ & 37 & Crime & 39 & Death of Kofi Annan & 61 \\
\hline 36 & & & Austrian journalist imprisoned in Turkey & 39 & Post-Brexit relations & 55 \\
\hline 37 & & & Fire in an asylum centre & 36 & Bilateral relations Egypt & 48 \\
\hline 38 & & & Russia/Ukraine & 32 & New video technology for referees & 43 \\
\hline 39 & & & Phone call AU-UAE & 20 & Football: training break Zamalek (EGY) & 41 \\
\hline 40 & & & Netanyahu visit in Austria (cancelled) & 16 & Football & 37 \\
\hline
\end{tabular}

aThose topics were afterwards aggregated to one: "State visit as-Sisi" as they treat different aspects of that same visit 
Open Access This article is licensed under a Creative Commons Attribution 4.0 International License, which permits use, sharing, adaptation, distribution and reproduction in any medium or format, as long as you give appropriate credit to the original author(s) and the source, provide a link to the Creative Commons licence, and indicate if changes were made. The images or other third party material in this article are included in the article's Creative Commons licence, unless indicated otherwise in a credit line to the material. If material is not included in the article's Creative Commons licence and your intended use is not permitted by statutory regulation or exceeds the permitted use, you will need to obtain permission directly from the copyright holder. To view a copy of this licence, visit http://creativecommons.org/licenses/by/4.0/.

\section{References}

Abdulla, Rasha A. 2007. The Internet in the Arab World: Egypt and Beyond. New York: P. Lang.

Aday, Sean, Henry Farrell, Deen Freelon, Marc Lynch, John Sides, and Michael Dewar. 2013. Watching from Afar. American Behavioral Scientist 57 (7): 899-919.

Ahern, T.J. 1984. Determinants of Foreign Coverage in US Newspapers. In Foreign news and the new world information order, ed. R.L. Stevenson, 217-36. Iowa: Iowa State Univ. Press.

Albritton, Robert B., and Jarol B. Manheim. 1983. News of Rhodesia: The Impact of a Public Relations Campaign. Journalism Quarterly 60 (4): 622-628.

Albritton, Robert B., and Jarol B. Manheim. 1985. Public Relations Efforts for the Third World: Images in the News. Journal of Communication 35 (1): 43-59.

Ayish, Muhammad I. 2012. The New Arab Public Sphere. Medien und politische Kommunikation - Naher Osten und islamische Welt. Berlin: Frank \& Timme.

Ayish, Muhammad I. 2013. Television Broadcasting in the Arab World: Political Democratization and Cultural Revivalism. In Arab Media. PGMC - Polity Global Media and Communication series, ed. Noha Mellor, et al., 85-102. New Jersey: Hoboken.

Banks, R. 2011. A Resource Guide to Public Diplomacy Evaluation. Los Angeles: Figueroa Press.

Bátora, Jozef. 2005. Public Diplomacy in Small and Medium-Sized States: Norway and Canada. Netherlands Institute of International Relations "Clingendael".

Bjola, Corneliu, and Markus Kornprobst. 2013. Understanding International Diplomacy: Theory, Practice and Ethics. New York: Routledge.

Blei, D.M., A.Y. Ng, and M.I. Jordan. 2003. Latent Diriclet Allocation. Journal of Machine Learning Research 3: 993-1022.

Brewer, Paul R., Joseph Graf, and Lars Willnat. 2003. Priming or Framing. International Communication Gazette 65 (6): 493-508.

Castells, Manuel. 2010. The Rise of the Network Society. Oxford: Wiley-Blackwell.

Chang, Tsan-Kuo. 1998. All Countries Not Created Equal to Be News. Communication Research 25 (5): 528-563.

Cooper, A.F., and B. Momani. 2011. Qatar and Expanded Contours of Small State Diplomacy. The International Spectator 46 (3): 113-128. https://doi.org/10.1080/03932729.2011.576181.

Cowan, Geoffrey, and Amelia Arsenault. 2008. Moving from Monologue to Dialogue to Collaboration: The Three Layers of Public Diplomacy. The ANNALS of the American Academy of Political and Social Science 616 (1): 10-30.

Dupree, J.D. 1971. International Communication: A View from "a Window on the World." International Communication Gazette 17 (4): 224-235.
Feinerer, Ingo, Kurt Hornik, and David Meyer. 2008. Text Mining Infrastructure in R. Journal of Statistical Software. https://doi. org/10.18637/jss.v025.105

Fitzpatrick, Kathy. 2010. The Future of U.S. Public Diplomacy. Leiden: Martinus Nijhoff Publishers.

Galtung, J., and M.H. Ruge. 1965. The Structure of Foreign News: The Presentation of the Congo, Cuba and Cyprus Crises in Four Norwegian Newspaper. Journal of Peace Research 2 (1): 64-91.

Gerbner, George, and George Marvanyi. 1977. The Many Worlds of the World's Press. Journal of Communication 27 (1): 52-66.

Golan, Guy. 2010. International Media Communication in a Global Age. New York: Routledge, 2010.

Golan, Guy, and Wayne Wanta. 2003. International Elections on US Network News. International Communication Gazette 65 (1): $25-39$.

Golan, Guy J. 2008. Where in the World Is Africa? International Communication Gazette 70 (1): 41-57.

Golan, Guy J., Thomas J. Johnson, and Wayne Wanta, eds. 2010. International Media Communication in a Global Age. Communication series. New York: Routledge.

Grün, Bettina, and Kurt Hornik. 2011. Topicmodels: An R Package for Fitting Topic Models. Journal of Statistical Software. https://doi. org/10.18637/jss.v040.i13

Habermas, Jürgen. 1991. The Structural Transformation of the Public Sphere: An Inquiry into a Category of Bourgeois Society. Cambridge, MA: MIT Press, 1991.

Haeuptli, Andrea. 2019. A New Transnational Arena? An Analysis of Cross-Border Web Traffic Towards Professional Online News Sites in the Arab World. Journal of Arab \& Muslim Media Research 12 (2): 145-167.

Hagen, Lutz M., Harald Berens, Reimar Zeh, and Daniela Leidner. 1998. Ländermerkmale als Nachrichtenfaktoren. In Wie die Medien die Welt erschaffen und wie die Menschen darin leben: Für Winfried Schulz, ed. Christina Holtz-Bacha, Helmut Scherer, and Norbert Waldmann, 59-82. Wiesbaden: VS Verlag für Sozialwissenschaften.

Jacobi, Carina, Wouter van Atteveldt, and Kasper Welbers. 2015. Quantitative Analysis of Large Amounts of Journalistic Texts Using Topic Modelling. Digital Journalism 4 (1): 89-106.

Jones, Timothy M., Peter van Aelst, and Rens Vliegenthart. 2012. Foreign Nation Visibility in U.S. News Coverage. Communication Research 40(3): 417-436.

Kamps, Klaus. 1998. Nachrichtengeographie. In Fernsehnachrichten: Prozesse, Strukturen, Funktionen, ed. Klaus Kamps and Miriam Meckel, 275-94. Wiesbaden, s.1.: VS Verlag für Sozialwissenschaften.

Kelaiaia, Abdessalem, and Hayet F. Merouani. 2013. Clustering with Probabilistic Topic Models on Arabic Texts. In Abdelmalek Amine, Otmane A. Mohamed and Ladjel Bellatreche (eds.). Modeling Approaches and Algorithms for Advanced Computer Applications (pp. 65-74). Cham: Springer International Publishing.

Kim, Kyungmo, and George A. Barnett. 1996. The Determinants of International News Flow. Communication Research 23 (3): 323-352.

Lee, Suman, and Hyehyun Hong. 2012. International Public Relations' Influence on Media Coverage and Public Perceptions of Foreign Countries. Public Relations Review 38 (3): 491-493.

Manheim, Jarol B., and Robert B. Albritton. 1984. Changing National Images: International Public Relations and Media Agenda Setting. American Political Science Review 78 (3): 641-657.

Marwa, Naili, Anja Chai, and Henda Ghézala. 2017. Arabic Topic Identification Based on Empirical Studies of Topic Models. Revue Africaine de la Recherche en Informatique et Mathématiques Appliquées INRIA. 
Melissen, Jan, ed. 2005. The New Public Diplomacy: Soft Power in International Relations. New York: Palgrave.

Nye, J.S. 2004. Soft Power: The Means to Success in World Politics. New York: Public Affairs.

Organisation for Economic Cooperation and Development. 2019. Database on Imigrants in OECD and Non-OECD Countries: DIOC. http://www.oecd.org/els/mig/dioc.htm.

Östgaard, Einar. 1965. Factors Influencing the Flow of News. Journal of Peace Research 2 (1): 39-63.

Pahlavi, P. 2007. Evaluating Public Diplomacy Programmes. The Hague Journal of Diplomacy 2: 255-281.

Pammet, James. 2014. Articulating Influence: Toward a Research Agenda for Interpreting the Evaluation of Soft Power, Public Diplomacy and Nation Brands. Public Relations Review 40: 50-59.

Perry, David. 1985. The Mass Media and Inference About Other Nations. Communication Research 12 (4): 595-614.

Samei, Marwa F. A. 2015. The European Union's Public Diplomacy Towards the Arab Spring: The Case of Egypt. The Hague Journal of Diplomacy 10 (2): 111-138.

Sarnelli, Viola, and Vera Lomazzi. 2019. The End of Pan-Arab Media? National, Transnational Media and Identity in Morocco, Tunisia and Jordan After 2011. International Communication Gazette 81 (5): 418-444.

Schulz, Winfried. 1976. Die Konstruktion von Realität in den Nachrichtenmedien: Analyse der aktuellen Berichterstattung. Freiburg Breisgau: Alber.

Schulz, Winfried. 1982. News Structure and People's Awareness of Political Events. International Communication Gazette 30 (3): 139-153.

Seib, Philip. 2014. New Media and Public Diplomacy in the New Arab World. In Media evolution on the eve of the Arab Spring, ed. Leila Hudson, Adel Iskander, and Mimi Kirk, 181-92. New York: Palgrave Macmillan.

Siegner, Alana, Jennifer Sowerwine, and Charisma Acey. 2018. Does Urban Agriculture Improve Food Security? Examining the Nexus of Food Access and Distribution of Urban Produced Foods in the United States: A Systematic Review. Sustainability 10 (9): 2988.

Spellerberg, Ian F., and Peter J. Fedor. 2003. A Tribute to Claude Shannon (1916-2001) and a Plea for More Rigorous Use of Species Richness, Species Diversity and the 'Shannon-Wiener' Index. Global Ecology and Biogeography 12 (3): 177-179.

Staab, Joachim F. 1990. The Role of News Factors in News Selection: A Theoretical Reconsideration. European Journal of Communication 5 (4): 423-443.

Statistisches Bundesamt. 2020. Ausländerstatistik. https://www-genes is.destatis.de/genesis//online/data?operation $=$ table $\&$ code $=12521$ $0002 \&$ levelindex $=0 \&$ levelid $=1579094288879$ (accessed January $23,2020)$.

Tiele, Annekaryn. 2010. Nachrichtengeographien der Tagespresse: Eine international vergleichende Nachrichtenwert-Studie. Berlin: Logos, 2010; Zugl.: Hannover, Hochsch. für Musik, Theater u. Medien, Inst. für Journalistik u. Kommunikationsforschung, Diss., 2010.
Voumard, Jérémie., Marc-Henri. Derron, and Michel Jaboyedoff. 2018. Natural Hazard Events Affecting Transportation Networks in Switzerland from 2012 to 2016. Natural Hazards and Earth System Sciences 18 (8): 2093-2109.

de Vries, Erik, Martijn Schoonvelde, and Gijs Schumacher. 2018. No Longer Lost in Translation: Evidence That Google Translate Works for Comparative Bag-of-Words Text Applications. Political Analysis 26 (4): 417-430.

Weichelt, Bryan, Marsha Salzwedel, Scott Heiberger, and Barbara C. Lee. 2018. Establishing a Publicly Available National Database of US News Articles Reporting Agriculture-Related Injuries and Fatalities. American journal of industrial medicine.

Westerståhl, Jörgen., and Folke Johansson. 1994. Foreign News: News Values and Ideologies. European Journal of Communication 9 (1): 71-89.

Wu, Hoaming Denis. 2000. Systemic Determinants of International News Coverage: A Comparison of 38 Countries. Journal of Communication 50 (2): 110-130.

Wu, Hoaming Denis. 2003. Homogeneity Around the World? Comparing the Systemic Determinants of International News Flow Between Develped and Developing Countries. International Communication Gazette 65 (1): 9-24.

Wu, Haoming Denis. 2016. Investigating the Determinants of International News Flow. Gazette 60 (6): 493-512.

Wu, H.D., and R. Coeman. 2009. Advancing Agenda-Setting Theory: The Comparative Strength and New Contingent Conditions of the Two Levels of Agenda-Setting Effects. Journalism \& Mass Communication Quarterly 86 (4): 775-789.

Zaharna, R. S. 2010. Battles to Bridges: U.S. Strategic Communication and Public Diplomacy After 9/11. New York: Palgrave Macmillan.

Zerfaß, A., and G. Bentele, eds. 2008. Public Relations Research: European and International Perspectives and Innovations. Wiesbaden: VS Verl. für Sozialwissenschaften.

Publisher's Note Springer Nature remains neutral with regard to jurisdictional claims in published maps and institutional affiliations.

Andrea Häuptli is currently a PhD student at the Department of Communication and Media Research at the University of Zurich, Switzerland. Her research focuses on the digital transformation of the public sphere, state-led strategic communication, the Arab public sphere, and automated text analysis.

Daniel Vogler PhD is Deputy Director of the Research Center for the Public Sphere and Society - University of Zurich, and Research Associate at the Department of Communications and Media Research at the University of Zurich. His main research interests are public relations, journalism and online communication. 